\title{
Growth performance and carcass characteristics of three Ethiopian goat breeds fed grainless diets varying in concentrate to roughage ratios
}

\author{
Ameha Sebsibe $^{1 \#}$, N.H. Casey ${ }^{1}$, W.A. van Niekerk ${ }^{1}$, Azage Tegegne ${ }^{2}$ and R.J. Coertze ${ }^{1}$ \\ ${ }^{1}$ Department of Animal \& Wildlife Sciences, University of Pretoria, Pretoria 0002, South Africa \\ ${ }^{2}$ International Livestock Research Institute, P.O. Box, 5689, Addis Ababa, Ethiopia
}

\begin{abstract}
Growth and carcass characteristics of three Ethiopian goat breeds, the Afar, Central Highland (CHG) and Long-eared Somali (LES) were evaluated using three grainless diets varying in concentrate:roughage ratios (diet 1 was 50:50, diet 2, 65:35 and diet 3, 80:20) under feedlot conditions. The roughage was native grass hay and the concentrate consisted of wheat bran and noug cake (Guizotia abyssinica). Seventy-two eight-month old intact male goats (24 per breed) were randomly allotted to the dietary treatments, fed for 126 days and slaughtered at an age of approximately 12 months. The LES had higher average daily gain (ADG), heavier slaughter, empty body (EBW) and carcass weights than Afar and CHG goats. Diet significantly affected ADG, but was similar on carcass traits except for dressing percentage (DP) on an EBW basis and some non-carcass components. The DP on an EBW basis was the highest on diet 1. Breed affected the DP, which ranged from 42.5 - 44.6\% and 54.3 - 55.8\% on slaughter weight and EBW basis, respectively. The LES had a greater buttock circumference and carcass compactness. The $\mathrm{pH}_{24}$ varied between 5.61 - 5.67 and chilling losses were between 2.5 and 3.1\%. The physical carcass composition (8-10 $0^{\text {th }}$ rib-cut) ranged from 72 - 73, $6.9-10.9$ and $17.1-20.2 \%$ for lean, fat and bone, respectively, and the fat content of the meat ranged from $10.3-14.0 \%$. Breed affected the weights of internal fat depots. The findings indicate that breed affected the carcass characteristics of the three Ethiopian goat breeds.
\end{abstract}

Keywords: Indigenous goats, carcass yield, carcass composition, primal cuts, non-carcass components

\#Corresponding author. E-mail: amehaus@yahoo.com

\section{Introduction}

The Ethiopian indigenous goat population, estimated at 23.3 million (Central Statistics Authority, 2004), has been characterized phenotypically (Farm Africa, 1996) and by microsatelite DNA markers into nine distinct genetic entities (Tesfaye et al., 2004). Ethiopia's domestic demand for goat meat is high (Gryseels \& Anderson, 1983) with goat meat realising higher prices than mutton or beef in eastern parts of the country (Farm Africa, 1996). Ethiopia is also competing in the world market through the exportation of goat meat to a number of Middle East countries (Ethiopian Export Promotion Agency, 2003). However, the production performances of these goat breeds have not been evaluated.

In general, the global demand for goat meat is growing (Gipson, 1998). This may have been because goat meat is an important part of the national diet and has a special religious significance in the Middle East. It is also an accepted red meat as part of the cultural heritage and tradition in Asia, Africa and some Mediterranean countries (www.mountainmeatgoats.com). Moreover, goat meat is characteristically lean, thus rich in nutrients that could attract health conscious consumers. However, the product can vary according to genotype, age, gender and nutrition (Casey et al., 2003; Dhanda et al., 2003).

The major feed resources in Ethiopia are native pasture, crop residues and agro-industrial by-products. The native pasture, however, is characterized by high seasonal variation in yield and quality and animals often lose condition during the dry season. Grains are expensive and economically not suitable to use as a supplement in animal nutrition. The challenge is to develop alternative feed resources that will sustain production throughout the year. This paper presents the growth performance and carcass characteristics of three selected goat breeds fed a grainless diet that included Ethiopian native grass hay, wheat bran and noug cake. 


\section{Materials and Methods}

Ninety young intact male goats of three breeds, the Afar, the Long-eared Somali (LES) and the Central Highland goat (CHG) were used in the study. The study was conducted at the Debre-Zeit Research Station of the International Livestock Research Institute, Ethiopia.

Thirty goats per breed were randomly allocated at eight per treatment to the three experimental treatments and six to a pre-experimental slaughter group. The three dietary treatments were different ratios of concentrate: roughage, viz., diet 1, 50:50 (8.5 MJ ME/kg dry matter, DM), diet 2, 65:35 (9.2 MJ ME/kg DM) and diet 3, 80:20 (10.0 MJ ME/kg DM). The roughage component was native pasture hay and the concentrate consisted of $79 \%$ wheat bran, $20 \%$ noug cake (Guizotia abyssinica) and $1 \%$ salt $(\mathrm{NaCl})$. The quantity of roughage and concentrate as per ratio of the diets was adjusted on the basis of body weight to meet the DM requirements of the goats (Kearl, 1982).

Feed DM and organic matter (OM) were determined according to AOAC (1990) and the neutral detergent fibre (NDF), acid detergent fibre (ADF) and acid detergent lignin (ADL) were analyzed according to Van Soest et al. (1991). Nitrogen (N) was measured using the micro-Kjeldahl procedure (AOAC, 1990). The calcium (Ca) was determined by wet digestion method using an Atomic Absorption Spectrophotometer (Perkin Elmer, 1982) and the phosphorus (P) using a continuous flow auto-analyzer (ChemLab, 1981). In vitro dry matter digestibility (IVDMD) was estimated by the methods of Tilley \& Terry as modified by Van Soest \& Robertson (1985).

Table 1 Chemical composition of the dietary components and experimental diets (g/kg dry matter - DM)

\begin{tabular}{lllllllllll}
\hline Item & DM & Ash & OM & CP & NDF & ADF & ADL & Ca & P & IVDMD \\
\hline Native grass hay & 917.8 & 88.7 & 911.3 & 50.6 & 720.8 & 389.3 & 38.0 & 5.3 & 2.8 & 48.0 \\
Wheat bran & 870.3 & 43.4 & 956.6 & 191.9 & 442.0 & 128.4 & 24.3 & 2.1 & 10.8 & 68.7 \\
Noug cake & 919.3 & 100.5 & 899.5 & 345.0 & 353.4 & 270.3 & 106.4 & 8.5 & 13.7 & 63.2 \\
Concentrate & 887.9 & 65.8 & 934.2 & 216.6 & 398.3 & 141.1 & 35.4 & 3.2 & 10.9 & 68.9 \\
Diet 1 & 897.8 & 81.1 & 918.9 & 153.1 & 579.6 & 267.2 & 33.9 & 3.9 & 7.9 & 57.0 \\
Diet 2 & 895.3 & 78.9 & 921.1 & 175.6 & 514.8 & 229.0 & 35.5 & 3.7 & 9.4 & 61.3 \\
Diet 3 & 891.5 & 70.6 & 929.4 & 196.2 & 436.4 & 187.3 & 30.9 & 3.0 & 10.8 & 66.7 \\
& & & & & & & & & &
\end{tabular}

$\mathrm{OM}$ - organic matter; CP - crude protein; NDF - neutral detergent fibre; ADL - acid detergent lignin;

$\mathrm{Ca}$ - calcium; P - phosphorus; IVDMD - in vitro dry matter digestibility (\%)

The goats were dewormed, dipped and vaccinated against known parasites and diseases during the quarantine period of 21 days and were adapted for 14 days to the experimental diets and pens. The animals were kept under roof in individual pens with access to clean water and a mineral block and fed the experimental diets for 126 days. They were weighed once a week in the morning before watering and feeding. Four goats did not complete the study period due to Cenhorosis and pneumonia.

An initial sample from each genotype was slaughtered to estimate the initial carcass mass, wholesale cuts and physical composition of the goats at the onset of the study. The stall-fed goats were slaughtered at ca. 12 months of age. The goats were weighed pre-fasting, fasted for 16 hours, but with access to water, reweighed and slaughtered by the Halal method (Kadim et al., 2003). The goats were slaughtered and dressed down using standard commercial techniques. The hot carcass comprised the body after removing the skin, head, fore feet (at the carpal-metacarpal joint), hind feet (at the tarsal-metatarsal joint), viscera and fat depots. Internal organs (kidneys, liver, heart, lungs, spleen and pancreas) and fat depots such as scrotal fat, pelvic, kidney and gut fat (omental + mesenteric fat) were also removed. Hot carcass weight (HCW) and the weights of blood, internal organs, testicles, fat depots and full and empty gastro-intestinal tracts were recorded. Empty body weight (EBW) excluded the gastro-intestinal tract contents. Dressing percentage (DP) was defined as the hot carcass weight expressed as a percentage of slaughter body weight (SBW). The total edible proportion (TEP) was the SBW minus the contents of gastro-intestinal tract, skin, head, feet and lungs and trachea.

Cold carcass weight (CCW) was measured after 24 hours of chilling at $4{ }^{\circ} \mathrm{C}$ and cooler shrinkage was calculated as the proportion of the difference between HCW and CCW to HCW. Carcass length (caudal edge 
of the last sacral vertebra to the dorso-cranial edge of the atlas), leg length and buttock circumference were also measured (Fisher \& De Boer, 1994). Carcass compactness was defined as the ratio of cold carcass weight to carcass length (Webb, 1992).

After removing the tail at the last sacral/first coccygeal vertebrae articulation, the cold carcass was split along the dorsal mid-line with a band saw. The left half of the carcass was partitioned into leg, loin, racks, shoulder and neck and breast and shank according to the Indian Standard Institution (1963). The rib section $\left(8-9-10^{\text {th }}\right)$ from the right half of each carcass was dissected and the tissues were separated to estimate the total carcass composition in terms of lean (muscle), bone and fat (Casey et al., 1988). The dissected lean and fat were minced together and the ether extract (fat) content measured (AOAC, 1990), which is highly correlated with the chemical composition of a dressed carcass (Field et al., 1963). Eye-muscle ( $m$. longissimus dorsi) area was measured after tracing the eye-muscle at the $12 / 13^{\text {th }}$ rib position. Fat thickness and total tissue depths were measured at the $12^{\text {th }}$ rib, $11 \mathrm{~cm}$ from the spinal cord on the left side of the carcass (Ponnampalam et al., 2003). The $\mathrm{pH}_{24}$ was measured on $m$. longissimus dorsi 24 hours post mortem with a penetrating glass electrode (Orion 9106) that was rinsed with distilled water after every reading and recalibrated after every fourth reading.

The data were analyzed using the General Linear Model procedures of SAS (SAS, 2001) according to a 3 x 3 factorial arrangement with breed and diet as main effects in a Completely Randomized Design. No significant breed by diet class interaction was noted for growth rate and most carcass traits, so the main effects were presented and discussed. Initial weight was included as a covariate for pre-slaughter and slaughter weights, EBW, carcass weights and weights of primal cuts. Significant differences between means were determined by multiple comparisons using the Fisher test (Samuels, 1989).

\section{Results and Discussions}

The crude protein (CP), NDF and IVDMD values of the native grass hay were comparable to the results reported by Zinash \& Seyoum (1991). The CP, NDF and ADF values for wheat bran and noug cake were also similar to those reported by Seyoum \& Zinash (1989) and Tesfaye et al. (2001). The low CP and high NDF values of the native grass hay suggested that it was of a poor quality roughage (Table 1).

Body weights and growth rates are presented in Table 2. The breed effect on final body weight (FBW) and ADG was highly significant $(\mathrm{P}<0.001)$, which is in line with the results of El-Hag \& El-Shargi (1996), Dhanda et al. (2001) and Mahgoub et al. (2005). The LES breed had the highest ADG. Diet 3 resulted in a higher $(\mathrm{P}<0.05)$ ADG than diet 2 but the results did not differ $(\mathrm{P}>0.05)$ from diet 1 . This finding may be due to small differences in ME levels used in the current study since the lowest ME level probably was not low enough to attain a statistical difference. The growth rates reported in Table 2 were within the range of 23 - 63 g/d reported for Tanzanian East African goats by Mtenga \& Kitaly (1990). However, indigenous goats, 15 - 18 months old, from the middle Rift Valley area of Ethiopia, grazing natural pastures supplemented with a concentrate (69\% wheat bran and 30\% noug cake) attained a higher ADG of $71.8 \mathrm{~g} / \mathrm{d}$ (Abule et al., 1998). The higher ADG could be ascribed to a lower proportion of wheat bran (69 vs. 79\%) in their concentrate compared to our experimental diets and better quality vegetation during the season. Dhakad et al. (2002) reported lower ADG for growing lambs when wheat bran replaced grain in the concentrate (75\% wheat bran and $22 \%$ groundnut cake) and suggested a threshold level of 50\% inclusion, a level that does not affect lamb growth adversely. The current result vis-à-vis the proportion of wheat bran used by Abule et al. (1998) indicates that a threshold level may also apply to goats. Nevertheless, the ADG of the LES was similar to those of the tropical breeds of Zaraibi (El-Gallad et al., 1988), Gaddi (Kumar et al., 1991), Malawi (Kirk et al., 1994), Batina (Kadim et al., 2003), the Indian goat (Sen et al., 2004) and semi-intensively managed Somali and Mid Rift Valley goats (Getahun, 2001) at similar age fed grain-based concentrate. The goats in the present study also had higher ADG than Mubende goats (Okello et al., 1994) and Malaysian intensively managed male Jamanapari x Kambing Katajang crosses (Mustapha \& Kamal, 1982) at comparable ages. The LES breed had the highest $(\mathrm{P}<0.001)$ FBW due to its better growth rate.

Breed had a significant effect on most of the carcass parameters (Table 3), while dietary effects were statistically similar for most traits, except for DP and some non-carcass components. Most carcass measurements between the initial carcasses of the three breeds were similar $(P>0.05)$. Statistical differences between the breeds (Table 3) were evident for most carcass traits after correcting for initial weight. The LES 
breed had the highest $(\mathrm{P}<0.001)$ pre-slaughter and slaughter weights, EBW, HCW and CCW. As with the growth performance, the Afar and CHG breeds had similar $(\mathrm{P}>0.05)$ values for these parameters.

Table 2 Body weight and growth rates (least square mean \pm s.e) of selected Ethiopian goat breeds stall-fed with a grainless diet

\begin{tabular}{|c|c|c|c|}
\hline Parameters & IBW (kg) & FBW (kg) & ADG (g) \\
\hline \multicolumn{4}{|l|}{ Breed } \\
\hline Afar & $13.11^{\mathrm{b}} \pm 0.17$ & $17.95^{\mathrm{b}} \pm 0.36$ & $36.7^{b} \pm 2.04$ \\
\hline CHG & $14.29^{\mathrm{a}} \pm 0.18$ & $18.38^{b} \pm 0.31$ & $34.7^{b} \pm 2.09$ \\
\hline LES & $14.76^{\mathrm{a}} \pm 0.17$ & $20.00^{\mathrm{a}} \pm 0.33$ & $43.9^{a} \pm 2.05$ \\
\hline \multicolumn{4}{|l|}{ Feeding regimen } \\
\hline Diet 1 & $14.06 \pm 0.18$ & $19.08 \pm 0.31$ & $37.7^{\mathrm{ab}} \pm 2.09$ \\
\hline Diet 2 & $14.27 \pm 0.17$ & $18.33 \pm 0.30$ & $35.0^{\mathrm{b}} \pm 2.04$ \\
\hline Diet 3 & $13.85 \pm 0.18$ & $18.93 \pm 0.30$ & $42.5^{a} \pm 2.05$ \\
\hline
\end{tabular}

IBW - initial body weight; FBW - final body weight; ADG - average daily gain

CHG - Central Highland goat; LES - Long-eared Somali

${ }^{\mathrm{a} b}$ Means within columns with different superscripts differ $(\mathrm{P}<0.05)$

Breed affected the DP that ranged from 42.5 to $44.6 \%$ and 54.3 to $55.8 \%$ on SBW and EBW basis, respectively. On a SBW basis LES and Afar had higher and similar $(\mathrm{P}>0.05)$ DP, whereas CHG had the lowest $(\mathrm{P}<0.01) \mathrm{DP}$. On an EBW basis, LES had the highest value $(\mathrm{P}<0.01)$. Literature reports indicated that DP in goats varies between 38 and $56 \%$ by breed, sex, age, weight and conformation (Anjaneyulu \& Joshi, 1995; El Hag \& El Shargi, 1996; Dhanda et al., 1999a; Getahun, 2001). According to Payne \& Wilson (1999) the definition of DP that excludes edible offal, reduces the relative contribution of goat meat to the national meat supply. Dishes are made from non-carcass components such as liver, kidney, intestines, tongue and others are commonly available in most parts of Ethiopia (Ewunetu et al., 1998). Total edible proportion (TEP) could be a more useful criterion for comparing yields by breed and production practices. In this study the TEP ranged from 60.9 to $63.8 \%$ of SBW with Afar having the highest $(\mathrm{P}<0.0001)$, followed by LES. Adissu (2001) reported comparable yields of total usable products for the Afar breed.

The DP on an EBW basis was the highest $(\mathrm{P}<0.01)$ on diet 1 . Diet 1 also tended $(\mathrm{P}>0.05)$ to have higher values for pre-slaughter and SBW, EBW, HCW, CCW and DP on a SBW basis. Kumar et al. (1991) reported that the plane of nutrition did not significantly affect carcass weights, DP and proportions of cuts in Gaddi goats at the age of 14 months. Reddy \& Raghavan (1988), Hatendi et al. (1992), El Hag \& El Shargi (1996) and Sheridan et al. (2003) recorded similar effects on DP on SBW and / or carcass weights. However, Mahgoub et al. (2005) indicated that increasing ME levels in the diet fed to Omani goats increased carcass weight, EBW and DP.

Chilling losses were higher $(\mathrm{P}<0.01)$ in the carcass of initial CHG probably due to their lower fat content (Table 4). However, the chilling loss was similar $(\mathrm{P}>0.05)$ between the fed groups, though the CHG had a $10 \%$ greater loss. Chilling losses ranging from 2.3 to $8.7 \%$ have been reported for different goat genotypes and weights (El Khidir et al., 1998; Getahun, 2001).

Breed affected rib-eye area, fat thickness and total tissue depth. The rib eye area of the fed genotypes ranged from 6.4 to $8.3 \mathrm{~cm}^{2}$ (Table 3). The LES had the larger area, though statistically similar to Afar. However, CHG had the lowest $(\mathrm{P}<0.001)$ rib-eye area. These values agree with the reports of Rao et al. (1985) and Getahun (2001) at similar weight or age.

Fat thickness in the initial carcass was not measurable and regarded as minimal. Among the stall-fed breeds, the CHG had the thinnest $(\mathrm{P}<0.0001)$ fat cover of the three goat breeds (Table 3). Total tissue depth (fat + lean) differed $(\mathrm{P}<0.0001)$, with the LES the highest and CHG the smallest.

The ultimate carcass $\mathrm{pH}$ of the initial slaughter group was between 5.78 and $5.94(\mathrm{P}<0.05)$. The $\mathrm{pH}$ range in the carcasses of the experimental groups was between 5.61 and 5.67 and fitted into the range of 5.49 to 5.86 reported and considered normal by various authors (Dahanda et al., 1999b; Arguello et al., 2005). The 
relatively higher $\mathrm{pH}$ (5.94) of the carcasses of pre-experimental slaughtered CHG group could have been due to a lower glycogen reserve caused by either physical/emotional stress or inadequate nutrition from the extensive management system. High ultimate $\mathrm{pH}$ values for goat meat are also reported for different breeds and muscles in the literature (Webb et al., 2005).

Table 3 Carcass characteristics of Ethiopian goats fed a grainless diet (least square mean and PSE)

\begin{tabular}{|c|c|c|c|c|c|c|c|}
\hline \multirow[b]{2}{*}{ Traits } & \multicolumn{3}{|c|}{ Initial $^{+}$} & \multicolumn{3}{|c|}{ Fed groups $^{++}$} & \multirow[b]{2}{*}{ PSE } \\
\hline & $\begin{array}{c}\text { Afar } \\
(n=6)\end{array}$ & $\begin{array}{c}\text { CHG } \\
(n=5)\end{array}$ & $\begin{array}{c}\text { LES } \\
(n=6)\end{array}$ & $\begin{array}{c}\text { Afar } \\
(n=23)\end{array}$ & $\begin{array}{c}\text { CHG } \\
(\mathrm{n}=22)\end{array}$ & $\begin{array}{c}\text { LES } \\
(n=23)\end{array}$ & \\
\hline Pre-slaughter weight (kg) & 14.7 & 14.5 & 14.7 & $18.94^{\mathrm{b}}$ & $19.44^{\mathrm{b}}$ & $21.16^{\mathrm{a}}$ & 0.38 \\
\hline Slaughter body weight (kg) & 13.8 & 13.9 & 13.9 & $17.95^{b}$ & $18.38^{b}$ & $20.00^{\mathrm{a}}$ & 0.33 \\
\hline Fasting loss (\%) & 6.12 & 4.32 & 5.39 & 5.23 & 5.31 & 5.39 & 0.30 \\
\hline Empty body weight (kg) & 11.15 & 11.24 & 11.25 & $14.59^{\mathrm{b}}$ & $14.38^{\mathrm{b}}$ & $15.66^{\mathrm{a}}$ & 0.28 \\
\hline Hot carcass weight (kg) & 5.98 & 5.91 & 5.98 & $8.02^{b}$ & $7.83^{b}$ & $8.75^{\mathrm{a}}$ & 0.17 \\
\hline Cold carcass weight (kg) & 5.79 & 5.62 & 5.78 & $7.81^{\mathrm{b}}$ & $7.59^{b}$ & $8.52^{\mathrm{a}}$ & 0.17 \\
\hline Chilling loss (\%) & $3.4^{\mathrm{b}}$ & $5.2^{\mathrm{a}}$ & $3.4^{\mathrm{b}}$ & 2.8 & 3.1 & 2.5 & 0.21 \\
\hline DP (SBW basis) & 43.1 & 42.5 & 42.9 & $44.6^{\mathrm{a}}$ & $42.5^{b}$ & $43.7^{\mathrm{a}}$ & 0.42 \\
\hline DP (EBW basis) & 53.5 & 52.5 & 53.1 & $55.0^{\mathrm{b}}$ & $54.3^{b}$ & $55.8^{\mathrm{a}}$ & 0.27 \\
\hline Total edible proportion (SBW) & 61.7 & 61.6 & 62.3 & $63.8^{\mathrm{a}}$ & $60.9^{b}$ & $62.1^{b}$ & 0.48 \\
\hline Carcass length $(\mathrm{cm})$ & 55.4 & 54.1 & 54.9 & 59.7 & 58.7 & 59.2 & 0.56 \\
\hline Leg length $(\mathrm{cm})$ & 23.1 & 23.7 & 23.4 & $23.5^{\mathrm{b}}$ & $25.5^{\mathrm{a}}$ & $25.3^{\mathrm{a}}$ & 0.31 \\
\hline Buttock circumference (cm) & 38.2 & 35.7 & 36.3 & $42.3^{b}$ & $43.3^{b}$ & $44.9^{\mathrm{a}}$ & 0.56 \\
\hline Compactness index (g/cm) & 103.1 & 102.9 & 104.6 & $130.8^{b}$ & $129.3^{b}$ & $145.6^{\mathrm{a}}$ & 2.69 \\
\hline Rib-eye area $\left(\mathrm{cm}^{2}\right)$ & 5.42 & 4.85 & 5.75 & $7.72^{\mathrm{a}}$ & $6.43^{b}$ & $8.26^{\mathrm{a}}$ & 0.28 \\
\hline Fat thickness (mm) & 0 & 0 & 0 & $1.86^{\mathrm{a}}$ & $1.18^{\mathrm{b}}$ & $2.06^{\mathrm{a}}$ & 0.11 \\
\hline Total tissue depth (mm) & $6.66^{\mathrm{a}}$ & $5.40^{\mathrm{b}}$ & $6.50^{\mathrm{a}}$ & $7.12^{b}$ & $6.29^{c}$ & $7.76^{\mathrm{a}}$ & 0.20 \\
\hline pH ultimate & $5.78^{b}$ & $5.94^{\mathrm{a}}$ & $5.82^{b}$ & 5.66 & 5.67 & 5.61 & 0.02 \\
\hline
\end{tabular}

\footnotetext{
${ }^{+}$Initial - slaughter made at the start of the study, ${ }^{++}$Fed groups - stall-fed

CHG - Central Highland goat; LES - Long-eared Somali;

SBW - slaughter body weight (SBW); EBW - empty body weight; PSE - pooled standard error

a b c Means within rows for different group with different superscripts differ $(\mathrm{P}<0.05)$
}

Conformation is an important visual criterion that has a bearing on the perceived market value of a carcass. Conformation, however, can be misleading since a subjective assessment of the conformation lamb carcasses accounts for $<10 \%$ of the variation in meat yield (Bruwer, 1984). Leg length $(\mathrm{P}<0.001)$, buttock circumference $(\mathrm{P}<0.01)$ and tail weight $(\mathrm{P}<0.01)$ differed between breeds. Leg length and tail weight were similar $(\mathrm{P}>0.05)$ in CHG and LES but Afar had the shortest leg length and smallest tails $(\mathrm{P}<0.01)$. The LES had a larger buttock circumference than Afar $(\mathrm{P}<0.01)$ and CHG $(\mathrm{P}<0.05)$. Carcass compactness ratios were 145.6 (LES), 130.8 (Afar) and $129.3 \mathrm{~g} / \mathrm{cm}$ (CHG) (P < 0.0001). Mourad et al. (2001) reported a higher compactness index $(0.19 \mathrm{~kg} / \mathrm{cm})$ than the present finding, which was mainly due to the shorter carcass length of West African Dwarf goats.

Carcass lengths $(58.7-59.7 \mathrm{~cm})$ did not differ $(\mathrm{P}>0.05)$ between the breeds and are comparable to those reported by Dhanda et al. (2001) for the Chevon group, except for Boer X Saanen goats $(62.1 \mathrm{~cm})$. However, the carcasses of Ethiopian indigenous goats were longer than West African Dwarf $(46.8 \mathrm{~cm})$ goats at the age of 12 - 18 months (Mourad et al., 2001) and Beetal x Assam local (44.5 - $47.6 \mathrm{~cm}$ ) goats (Saikia et al., 1996).

Fasting loss was similar ( $\mathrm{P}>0.05$ ) between breeds and diets and ranged from 5.23 to $5.39 \%$ in the stall-fed goats (Table 3). This finding is in agreement with the starvation shrinkage reported by Ameha \& Mathur (2000).

The SBW was positively correlated with rib-eye area, but the coefficients varied between breeds, $r=0.51$; $P<0.01$ for LES, $r=0.33$ for Afar and $r=0.19$ for CHG. The correlation between compactness 
index and rib-eye area was also positive and significant for LES $(r=0.73 ; \mathrm{P}<0.0001)$ and Afar $(\mathrm{r}=0.41$; $\mathrm{P}<0.05)$, but for CHG it was not significant $(r=0.28)$. Generally most measures of fat (physical fat, chemical fat, fat thickness and total internal fat) were positively correlated ranging from 0.53 to 0.86 .

The physical composition, chemical fat, proportion of primal cuts, lean: bone and lean: fat ratios are shown in Table 4. Comparison of the composition of carcass of the initial slaughtered group with the carcass of fed groups indicated that the bone proportions decreased $(\mathrm{P}<0.01)$ and the fat increased $(\mathrm{P}<0.001)$ in the fed groups. The findings agree with Hatendi et al. (1992) and Mahgoub et al. (2005) who reported that the initial slaughter groups had lower carcass fat values than the fed groups. Singh et al. (1991) and Dhanda et al. (1999a) also documented that the percentage of bone decreased significantly with age and weight.

Among the initially slaughtered groups, CHG had the lowest fat proportion. The stall-fed CHG made considerable improvement in its fat proportion (3.3 times over its initial fat proportion). However, it still had the lowest fat proportion ( $\mathrm{P}<0.001)$ compared to LES and Afar under feedlot conditions. The same breed had the lowest $(\mathrm{P}<0.001)$ chemical fat of all the breeds tested (Table 4). Significant differences in carcass fat content between goat breeds were also reported by Johnson et al. (1995).

Considering the lower fat values recorded in CHG for chemical fat $(\mathrm{P}<0.001)$, physical fat ( $\mathrm{P}<0.001)$, fat thickness $(\mathrm{P}<0.0001)$ and total internal fat $(\mathrm{P}<0.01)$, this breed was assumed to be less physiologically mature than the other breeds. Snowder et al. (1994) used similar criteria. The DP of CHG was also lower $(\mathrm{P}<0.01)$ probably due to the lesser quantity of fat in the same genotype.

Table 4 Physical composition, chemical fat, proportion of primal cuts, lean: bone and lean: fat ratios (least square mean and PSE) of selected Ethiopian goats stall-fed with a grainless diet

\begin{tabular}{lccccccc}
\hline \multirow{2}{*}{ Traits } & \multicolumn{5}{c}{ Initial } & \multicolumn{3}{c}{ Fed } & \multirow{2}{*}{ PSE } \\
\cline { 2 - 6 } & Afar & CHG & LES & Afar & CHG & LES & \\
\hline Rib physical composition (\%) & & & & & & & \\
$\quad$ Lean & 73.9 & 76.9 & 76.8 & 72.6 & 72.9 & 72.0 & 0.77 \\
$\quad$ Bone & 19.8 & 21.4 & 19.2 & $18.2^{\mathrm{b}}$ & $20.2^{\mathrm{a}}$ & $17.1^{\mathrm{b}}$ & 0.57 \\
$\quad$ Fat & $6.3^{\mathrm{a}}$ & $1.6^{\mathrm{b}}$ & $3.9^{\mathrm{ab}}$ & $9.1^{\mathrm{b}}$ & $6.9^{\mathrm{c}}$ & $10.9^{\mathrm{a}}$ & 0.58 \\
$\quad$ Rib chemical fat (\% DM) & 4.39 & 2.16 & 2.34 & $13.4^{\mathrm{a}}$ & $10.3^{\mathrm{b}}$ & $14.0^{\mathrm{a}}$ & 0.66 \\
Proportion of primal cuts (\%) & & & & & & & \\
$\quad$ Leg & 33.20 & 33.30 & 33.80 & 32.66 & 32.05 & 32.40 & 0.27 \\
Loin & 9.76 & 9.88 & 9.32 & $10.43^{\mathrm{a}}$ & $9.78^{\mathrm{b}}$ & $10.08^{\mathrm{a}}$ & 0.17 \\
$\quad$ Rack & 14.23 & 13.99 & 13.72 & 14.25 & 14.47 & 14.38 & 0.24 \\
$\quad$ Breast \& shank & 14.06 & 12.96 & 13.40 & 13.29 & 12.98 & 13.39 & 0.30 \\
$\quad$ Shoulder \& neck & 28.77 & 29.82 & 29.76 & 29.37 & 30.74 & 29.73 & 0.41 \\
Ratio & & & & & & & \\
$\quad$ Lean : bone & 3.80 & 3.67 & 4.09 & $4.11^{\mathrm{a}}$ & $3.53^{\mathrm{b}}$ & $4.44^{\mathrm{a}}$ & 0.14 \\
Lean : fat & $12.37^{\mathrm{c}}$ & $51.70^{\mathrm{a}}$ & $20.92^{\mathrm{b}}$ & $8.70^{\mathrm{b}}$ & $13.36^{\mathrm{a}}$ & $7.30^{\mathrm{b}}$ & 0.96 \\
Meat : bone & 4.11 & 3.75 & 4.30 & $4.57^{\mathrm{a}}$ & $4.03^{\mathrm{b}}$ & $5.01^{\mathrm{a}}$ & 0.16 \\
& & & & & & & \\
CHG - Centat & & & & & & &
\end{tabular}

CHG - Central Highland goat; LES - Long-eared Somali; PSE - pooled standard error

a b c Means within rows for different groups with different superscripts differ $(\mathrm{P}<0.05)$

Diet had no significant $(\mathrm{P}>0.05)$ effect on the physical composition of the carcass. Similar findings were reported by Reddy \& Raghavan (1988) and El-Gallad et al. (1988). The proportions of the primal cuts were similar between the breeds for each slaughtered group (initial and fed). As for the composition, diet had no significant effect on the proportions of the primal cuts. These results corroborate with the literature (Kumar et al., 1991; Ameha \& Mathur, 2000). All the weights of the primal cuts except the rack, were significantly affected by breed after correcting for initial weight. The LES had the heaviest $(\mathrm{P}<0.001$, $\mathrm{P}<0.05$ ) bone in weights for leg, breast and shank, loin and shoulder and neck. With regard to percent cuts, all the cuts were similar between the genotypes except the loin, which was lower $(\mathrm{P}<0.05)$ in CHG.

Lean to bone and meat (lean + fat) to bone ratios of the initial carcass were similar between genotypes. However, CHG had the highest lean : fat ratio (Table 4) due to its lowest fat proportion. Considering the fed 
genotypes, LES and Afar yielded similar lean : bone ratio and CHG had the lowest $(\mathrm{P}<0.001)$ ratio. Moreover, LES and Afar had comparable $(\mathrm{P}>0.05)$ lean : fat and meat : bone ratios but CHG had a lower meat : bone $(\mathrm{P}<0.001)$ and wider $(\mathrm{P}<0.001)$ lean : fat ratio. The effect of genotype on the different ratios was also reported by Dhanda et al. (1999a) and Getahun (2001). Carcass composition (ribs $9-11^{\text {th }}$ ) of Zaraibi yearling goats fed different concentrate to roughage ratios (El-Gallad et al., 1988) was 69.3 - 75.0, 5.0 - 12.6, 16.1 - 20.0, 4.3 - $5.1 \%$ and 3.8 - 5.2 for lean, fat, bone, chemical fat and meat : bone ratio, respectively. These values are comparable with the present findings except that Ethiopian yearling goats fed a grainless diet had higher chemical fat (10.3 - 14.0\%) and meat : bone ratios (4.03 - 5.01).

Table 5 Weights and proportion of non-carcass components of Ethiopian goats (least square mean and PSE)

\begin{tabular}{|c|c|c|c|c|c|c|c|}
\hline \multirow{2}{*}{ Traits } & \multicolumn{3}{|c|}{ Initial } & \multicolumn{3}{|c|}{ Fed } & \multirow{2}{*}{ PSE } \\
\hline & Afar & $\mathrm{CHG}$ & LES & Afar & CHG & LES & \\
\hline \multicolumn{8}{|l|}{ Weights } \\
\hline Liver (g) & 279.3 & 294.8 & 320.8 & $286.4^{\mathrm{c}}$ & $312.8^{b}$ & $341.8^{\mathrm{a}}$ & 8.20 \\
\hline Heart (g) & 80.3 & 93.0 & 89.7 & $105.2^{\mathrm{b}}$ & $105.4^{\mathrm{b}}$ & $120.9^{\mathrm{a}}$ & 2.76 \\
\hline Kidney (g) & 50.6 & 51.4 & 54.5 & $53.7^{\mathrm{b}}$ & $58.6^{\mathrm{a}}$ & $61.6^{\mathrm{a}}$ & 1.08 \\
\hline Lung \& trachea (g) & 180.3 & 184.6 & 182.5 & $183.7^{\mathrm{b}}$ & $200.2^{\mathrm{a}}$ & $204.3^{a}$ & 4.00 \\
\hline Spleen (g) & $20.8^{b}$ & $23.8^{\mathrm{ba}}$ & $31.5^{\mathrm{a}}$ & $24.8^{b}$ & $25.3^{\mathrm{b}}$ & $33.9^{\mathrm{a}}$ & 1.49 \\
\hline Head (kg) & 0.97 & 0.99 & 0.98 & $1.17^{\mathrm{b}}$ & $1.23^{\mathrm{a}}$ & $1.25^{\mathrm{a}}$ & 0.01 \\
\hline Skin (kg) & 0.98 & 1.05 & 0.99 & $1.21^{\mathrm{b}}$ & $1.29^{\mathrm{b}}$ & $1.39^{\mathrm{a}}$ & 0.03 \\
\hline GIT empty (kg) & 0.87 & 0.90 & 0.97 & $1.07^{\mathrm{b}}$ & $1.12^{\mathrm{b}}$ & $1.20^{\mathrm{a}}$ & 0.02 \\
\hline Blood (kg) & 0.59 & 0.62 & 0.63 & $0.69^{b}$ & $0.76^{\mathrm{a}}$ & $0.78^{\mathrm{a}}$ & 0.01 \\
\hline Pancreas (g) & 19.8 & 21.0 & 19.0 & 26.3 & 26.9 & 28.1 & 0.85 \\
\hline Total internal organs (kg) & 0.66 & 0.68 & 0.71 & $0.68^{c}$ & $0.73^{b}$ & $0.79^{\mathrm{a}}$ & 0.01 \\
\hline GIT full (kg) & 3.54 & 3.51 & 3.59 & $4.33^{c}$ & $5.15^{b}$ & $5.62^{\mathrm{a}}$ & 0.13 \\
\hline Digestive contents (kg) & 2.7 & 2.6 & 2.6 & $3.3^{c}$ & $4.0^{\mathrm{b}}$ & $4.4^{\mathrm{a}}$ & 0.12 \\
\hline Feet (kg) & 0.41 & 0.43 & 0.41 & $0.45^{b}$ & $0.49^{\mathrm{a}}$ & $0.49^{\mathrm{a}}$ & 0.01 \\
\hline Testicles, other genitals (g) & $172.0^{\mathrm{ab}}$ & $188.8^{\mathrm{a}}$ & $143.8^{\mathrm{b}}$ & 222.7 & 213.5 & 229.6 & 5.98 \\
\hline Tail (g) & 19.0 & 16.8 & 19.8 & $23.0^{b}$ & $29.1^{\mathrm{a}}$ & $27.5^{\mathrm{a}}$ & 1.06 \\
\hline \multicolumn{8}{|l|}{ Proportions on EBW } \\
\hline Kidney & 0.55 & 0.55 & 0.58 & 0.38 & 0.41 & 0.38 & 0.01 \\
\hline Liver & $2.55^{b}$ & $2.66^{\mathrm{ba}}$ & $2.88^{\mathrm{a}}$ & 2.03 & 2.15 & 2.13 & 0.04 \\
\hline Heart & $0.74^{\mathrm{b}}$ & $0.83^{\mathrm{a}}$ & $0.81^{\mathrm{ab}}$ & 0.75 & 0.73 & 0.75 & 0.01 \\
\hline Lung \& trachea & 1.79 & 1.67 & 1.63 & $1.30^{\mathrm{b}}$ & $1.39^{\mathrm{a}}$ & $1.28^{\mathrm{b}}$ & 0.02 \\
\hline Spleen & $0.24^{\mathrm{b}}$ & $0.26^{\text {ba }}$ & $0.32^{\mathrm{a}}$ & $0.17^{\mathrm{b}}$ & $0.17^{b}$ & $0.21^{\mathrm{a}}$ & 0.01 \\
\hline Head & 8.82 & 8.95 & 8.79 & $8.36^{\mathrm{a}}$ & $8.53^{a}$ & $7.81^{b}$ & 0.10 \\
\hline Skin & 8.97 & 9.43 & 8.95 & 8.59 & 8.82 & 8.70 & 0.13 \\
\hline GIT empty & 7.9 & 8.1 & 8.7 & 7.6 & 7.8 & 7.5 & 0.15 \\
\hline Blood & 5.38 & 5.59 & 5.66 & $4.91^{\mathrm{b}}$ & $5.25^{a}$ & $4.88^{b}$ & 0.07 \\
\hline Pancreas & 0.18 & 0.19 & 0.17 & 0.19 & 0.19 & 0.18 & 0.01 \\
\hline Total internal organs & 6.05 & 6.16 & 6.38 & 4.83 & 5.02 & 4.93 & 0.06 \\
\hline Digesta (SBW basis) & 19.6 & 19.1 & 19.1 & $18.8^{b}$ & $21.8^{\mathrm{a}}$ & $21.6^{\mathrm{a}}$ & 0.55 \\
\hline Feet & 3.7 & 3.9 & 3.7 & $3.2^{\mathrm{ab}}$ & $3.4^{\mathrm{a}}$ & $3.1^{\mathrm{b}}$ & 0.06 \\
\hline Testicles, other genitals & $1.57^{\mathrm{a}}$ & $1.69^{\mathrm{a}}$ & $1.30^{\mathrm{b}}$ & $1.58^{\mathrm{a}}$ & $1.47^{b}$ & $1.43^{b}$ & 0.03 \\
\hline
\end{tabular}

EBW - empty body weight; GIT - gastro-intestinal tract; CHG - Central Highland goat; LES - Long-eared Somali; PSE - pooled standard error

a b c Means within rows for different groups with different superscripts differ $(\mathrm{P}<0.05)$

The weights and proportion of non-carcass components of Ethiopian goats are presented in Table 5. Breed significantly affected the weights of most edible and non-edible components of stall-fed goats. El Hag \& El Shargi (1996) and Kadim et al. (2003) also observed genotype effects in different goats. The LES had the heaviest $(\mathrm{P}<0.001)$ weights for liver, heart, kidney, total internal organ and empty GIT. The weights of blood, full GIT, digestive contents, skin and feet were significantly affected by breed. The proportions of 
head, blood and feet on EBW basis and digestive contents on SBW basis also differed between breeds. Most of the weights of non-carcass components are comparable with the report of Getahun (2001) for Somali goats. The head and the skin proportions of Maradi (Adebowale, 1981) and South African indigenous goats (Tshabalala et al., 2003) were also similar to Ethiopian goats. The weights of kidney, pancreas and total internal organs were affected by diet and these weights were less $(\mathrm{P}<0.01)$ in diet 1 . Significant effect of diet on pluck weight was also reported in Mubende goats (Okello et al., 1994). However, the other non-carcass components were not affected $(\mathrm{P}>0.05)$ by diet. This finding agrees with those of Kumar et al. (1991) and El Hag \& El Shargi (1996).

Distribution of non-carcass fat of Ethiopian goats is shown in Table 6. In the carcass of initial sample, breed did not significantly affect the weight of internal fats. However, each fat depot of stall-fed goats was significantly affected by breed and did not differ $(\mathrm{P}>0.05)$ between dietary treatments. As for the carcass traits, CHG had the lowest scrotal fat $(\mathrm{P}<0.001)$, kidney, pelvic, gut fat $(\mathrm{P}<0.05)$ and total internal fat $(\mathrm{P}<0.01)$ compared to the other breeds. The values obtained for the LES were the highest and comparable with those of Afar goats. Differences in deposition of internal fat in various breeds of goats were also reported by Mahgoub \& Lu (1998) and Kadim et al. (2003).

Table 6 Distribution of non-carcass fat of Ethiopian indigenous goats fed a grainless diet (least square mean and PSE)

\begin{tabular}{lccccccc}
\hline \multirow{2}{*}{ Traits } & \multicolumn{3}{c}{ Initial } & \multicolumn{3}{c}{ Fed } & PSE \\
\cline { 2 - 6 } & Afar & CHG & LES & Afar & CHG & LES & \\
\hline Weights & 17.3 & 7.2 & 13.7 & $58.44^{\mathrm{b}}$ & $43.78^{\mathrm{c}}$ & $69.92^{\mathrm{a}}$ & 3.72 \\
$\quad$ Scrotal fat (g) & 26 & 12.4 & 19.2 & $132.7^{\mathrm{a}}$ & $100.9^{\mathrm{b}}$ & $137.6^{\mathrm{a}}$ & 10.21 \\
Kidney fat (g) & 10.2 & 4.0 & 11.2 & $27.3^{\mathrm{b}}$ & $24.7^{\mathrm{b}}$ & $32.1^{\mathrm{a}}$ & 1.73 \\
Pelvic fat (g) & 95.83 & 66.20 & 93.83 & $357.5^{\mathrm{a}}$ & $324.6^{\mathrm{b}}$ & $388.0^{\mathrm{a}}$ & 20.68 \\
Gut fat (g) & 0.149 & 0.089 & 0.137 & $0.576^{\mathrm{a}}$ & $0.494^{\mathrm{b}}$ & $0.628^{\mathrm{a}}$ & 0.03 \\
Total non-carcass fat & & & & & & & \\
(kg) & & & & & & & \\
Percent on EBW & 0.16 & 0.06 & 0.12 & $0.41^{\mathrm{a}}$ & $0.30^{\mathrm{b}}$ & $0.43^{\mathrm{a}}$ & 0.02 \\
Scrotal fat & 0.24 & 0.11 & 0.17 & $0.93^{\mathrm{a}}$ & $0.69^{\mathrm{b}}$ & $0.86^{\mathrm{a}}$ & 0.06 \\
Kidney fat & $0.09^{\mathrm{a}}$ & $0.04^{\mathrm{b}}$ & $0.10^{\mathrm{a}}$ & 0.19 & 0.17 & 0.20 & 0.01 \\
Pelvic fat & 0.87 & 0.59 & 0.85 & 2.54 & 2.23 & 2.41 & 0.13 \\
Gut fat & 1.35 & 0.80 & 1.24 & $4.08^{\mathrm{a}}$ & $3.40^{\mathrm{b}}$ & $3.90^{\mathrm{a}}$ & 0.19 \\
Total non-carcass fat & & & & & & & \\
\hline
\end{tabular}

EBW - empty body weight; CHG - Central Highland goat; LES - Long-eared Somali;

PSE - pooled standard error

a b c Means within rows for different group with different superscripts differ $(\mathrm{P}<0.05)$

Comparison of stall-fed Ethiopian goats with tropical breeds, such as Indian goats (Sen et al., 2004), at similar age and slaughter weight indicated that Ethiopian goats had less total non-carcass fat (3.01 vs. 6.74\% on SBW basis) but more chemical fat (12.6 vs. 3.2\%) than the Indian goats. The difference in the non-carcass fat can mainly be contributed to breed. However, the difference in chemical fat may be due to the difference in sample location and breed. Moreover, Ethiopian indigenous goats had more chemical fat (10.3 - 14.0 vs. 4.3 - 5.1\%) compared to yearling stall-fed Zaraibi goats of Egypt (El-Gallad et al., 1988). The Ethiopian goats had less total non-carcass fat and relatively higher carcass fat, which may help to minimize chilling losses and improve the eating quality of the meat. Owen et al. (1978) indicated that even when the market requirement is for a lean carcass, a certain level of carcass fat (10 to 15\%) could be desirable from the consumer's point of view so that the cooked meat does not become too dry. Mariniva et al. (2001) also documented that goat meat lacks juiciness and an increased amount of subcutaneous and intermuscular fat would prevent the carcass from drying out during hanging. 


\section{Conclusion}

This study indicated that breed contributed to differences in growth rates and carcass characteristics, which were influenced by diet. The breed, LES had better growth rates, heavier body and carcass weights with a higher fat content followed by the Afar breed. This shows the potential of LES goats as meat producing animals under feedlot systems using a grainless diet (Diet 1, $8.5 \mathrm{MJ} \mathrm{ME} / \mathrm{kg} \mathrm{DM}$ and $153 \mathrm{~g} \mathrm{CP} / \mathrm{kg}$ $\mathrm{DM})$. The stall-feeding results also demonstrated the advantage of supplementation to grazing/browsing goats under the smallholders systems, a strategy that should be adopted by goat owners. The feed resources used in this study are locally available and their use will greatly increase meat production for the export and domestic market. On the basis of various carcass and non-carcass fat values, CHG was assumed to be the less physiologically mature breed.

Compared to reported chilling losses (2.3 - 8.7\%) for different goats and weights, the results obtained in the present study suggest relatively low values. This may be due to higher carcass fat in Ethiopian goats or a difference of the chilling environments. Therefore, it is suggested that the chilling losses of more carcasses representative of the LES and Afar breeds be quantified in commercial abattoirs. Such information will contribute to the determination of the optimum slaughter weight for these breeds at which chilling losses are minimal with suitable eating qualities.

\section{Acknowledgements}

The authors gratefully acknowledge the technical and financial support of the Amhara Regional Agricultural Research Institute, Ethiopian Agricultural Research Organization (EARO/ARTP), International Livestock Research Institute (ILRI), Mehari Endale (Veterinary Faculty) and technical personnel of the University of Pretoria.

\section{References}

Abule Ebro, Amsalu Sisay \& Tesfaye Alemu, 1998. Effect of level of substituting of Lablab (Dolichos lablab) for concentrate on growth rate and efficiency in post weaning goats. In: Proc. Ethiopian Society of Animal Production. pp. 264-269.

Adebowale, E.A., 1981. The feeding value of cowpea husks (Vigna uniquiculata walp.) in rations for goats. Turrialba. 31, 141-145.

Ameha Sebsibe \& Mathur, M.M., 2000. Effect of concentrate supplementation on carcass characteristics of stall-fed Barbari kids. Indian J. Anim. Nutr. 17, 304-310.

Anjaneyulu, A.S.R. \& Joshi, H.B., 1995. Carcass characteristics and composition of goat meat in Indian breeds- an overview. In: National Symposium on Production and Marketing of Goat Meat, CIRG and ISSGPU, India.

AOAC, 1990. Official Methods of Analysis. $15^{\text {th }}$ ed., Association of Analytical Chemists, Virginia, USA, $684 \mathrm{pp}$.

Arguello, A., Castro, N., Capote, J. \& Solomon, M., 2005. Effects of diet and live weight at slaughter on kid meat quality. Meat Sci. 70, 173-179.

Bruwer, G.G., 1984. Hoofstuk 6. Evaluering van karkasopbrengs en vleisgehalte met betrekking tot die huidige klassifikasie en graderingstelsel: 6.3.3.4. Subjektiewe vetheid- en bouvorm-evaluering ten opsigte van beramingsakkuraatheid. In: Objektiewe evaluering van die karkasgraderingstelsel vir lammers en skape in die R.S.A. MSc (Agric) thesis, University of Stellenbosch, South Africa.

Casey, N.H., Van Niekerk, W.A. \& Spreeth, E.B., 1988. Fatty acid composition of subcutaneous fat of sheep grazed on eight different pastures. Meat Sci. 23, 55-63.

Casey, N.H., Van Niekerk, W.A. \& Webb, E.C., 2003. Goat Meat. In: Encyclopedia of Food Sciences and Nutrition, Eds. Caballero, B., Trugo, L. \& Finglass, P., Academic Press, London. pp. 2937-2944.

Central Statistics Authority, 2004. The 2001/02 Ethiopian Agricultural Sample Enumeration, Executive Summary, May 2004, Addis Ababa, Ethiopia.

ChemLab Instruments Ltd., 1981. Continuous Flow Analysis. Method Sheet No. CW $2-008-17$, Horn Chruch, Essex, UK.

Dhakad, A., Garg, A.K., Singh, P. \& Agrawal, D.K., 2002. Effect of replacement of maize grain with wheat bran on the performance of growing lambs. Small Rumin. Res. 43, 227-234. 
Dhanda, J.S., Taylor, D.G., McCosker, J.E. \& Murray, P.J., 1999a. The influence of goat genotype on the production of Capretto and Chevon carcasses. 3. Dissected carcass composition. Meat Sci. 52, 369-374.

Dhanda, J.S., Taylor, D.G, Murray, P.J. \& McCosker, J.E., 1999b. The influence of goat genotype on the production of Carpetto and Chevon carcasses. 2. Meat quality. Meat Sci. 52, 363-367.

Dhanda, J.S., Taylor, D.G., Murray, P.J. \& McCosker, J.E., 2001. Growth, carcass and meat quality of different goat genotypes. www.pcmconsulting.com.au/goats/

Dhanda, J.S., Taylor, D.G., Murray, P.J., Pegg, R.B. \& Shand, P.J., 2003. Goat meat production: Present status and future possibilities. Asian-Aust. J. Anim. Sci. 16, 1842-1852.

El-Gallad, T.T., Allam, S.M., Gihad, E.A. \& El-Bedawy, T.M., 1988. Effect of energy intake and roughage ratio on the performance of Egyptian Nubian (Zaraibi) kids from weaning to one year of age. Small Rumin. Res. 1, 343-353.

El Hag, M.G. \& El Shargi, K.M., 1996. Feedlot performance and carcass characteristics of local (Dhofari) and exotic (Cashmere) goats fed on a high-fibre by-products diet supplemented with fish sardine. Asian-Aust. J. Anim. Sci. 9, 398-396.

El Khidir, I.A., Babiker, S.A. \& Shafie, S.A., 1998. Comparative feedlot performance and carcass characteristics of Sudanese desert sheep and goats. Small Rumin. Res. 30, 147-151.

Ethiopian Export Promotion Agency, 2003. Meat export statistics. EEPA, Addis Ababa, Ethiopia.

Ewunetu, E., Rege, J.E.O., Anindo, D.O., Hibret, A. \& Alemu, Y., 1998. Carcass and edible non-caracss component yields in Menz and Horro ram lambs. Proc. Ethiopian Society of Animal Production. pp. 217-222.

Farm Africa, 1996. Goat Types of Ethiopia and Eritrea. Physical description and management systems. Published jointly by Farm Africa, London, UK, and the International Livestock Research Institute, Nairobi, Kenya. pp. 1-76.

Field, R.A., Kemp, J.D. \& Varney, W.Y., 1963. Indices for lamb carcass composition. J. Anim. Sci. 22, 218.

Fisher, A.V. \& De Boer, H., 1994. Carcass measurements and dissection procedures. The EAAP standard method of sheep carcass assessment. Livest. Prod. Sci. 38, 149-159.

Getahun Legesse, 2001. Growth pattern and carcass characteristics of Somali and Mid-rift valley goats. MSc thesis, Alemaya Univesity, Ethiopia.

Gipson, T.A., 1998. Current market trends and potential for meat goat production. J. Anim. Sci. 76 (1) (Abstract).

Gryseels, G. \& Anderson, F.M., 1983. Research on farm and livestock productivity in the central highlands: Initial results, 1977-1980. Research Report. International Livestock Centre for Africa (ILCA), Addis Abeba, Ethiopia.

Hatendi, P.R., Smith, T., Ndlovu, L. \& Mutisi, C., 1992. Fattening mature indigenous (Matabele) goats: Effects on animal performance, body and carcass composition. In: Small Ruminant Research and Development in Africa, Proc. First Biennial Conference of the African Small Ruminant Research Network, Nairobi, Kenya.

Indian Standard Institution, 1963. Indian Standard Specification for mutton and goat flesh: Fresh, chilled and frozen. IS.2536. Indian Standard Institution. New Delhi, India.

Johnson, D.D., McGowan, C.H., Nurse, G. \& Anous, M.R., 1995. Breed type and sex effects on carcass traits, composition and tenderness of young goats. Small Rumin. Res. 17, 57-63.

Kadim, I.T., Mahgoub, O., Al-Ajmi, D.S., Al-Maqbaly, R.S., Al-Saqri, N.M. \& Ritchie, A., 2003. An evaluation of the growth, carcass and meat quality characteristics of Omani goat breeds. Meat Sci. 66, 203-210.

Kearl, L.C., 1982. Nutrient requirements of ruminants in developing countries. International feedstuff Institute, Uttah, USA.

Kirk, J.A., Cooper, R.A. \& Kamwanja, L.A., 1994. Growth, carcass composition and its prediction in the indigenous Malawi goats. J. Anim. Sci. 58, 480 (Abstract).

Kumar, S., Tiwari, S.P. \& Narang, M.P., 1991. Effect of different planes of nutrition on carcass characteristics in Gaddi goats. Indian Vet. J. 68, 953-956.

Mahgoub, O. \& Lu, C.D., 1998. Growth body composition and carcass tissue distribution in goats of large and small sizes. Small Rumin. Res. 27, 267-278. 
Mahgoub, O., Lu, C.D., Hameed, M.S., Richie, A., Al-Halhali, A.S. \& Annamalai, K., 2005. Performance of Omani goats fed diets containing various metabolizable energy densities. Small Rumin. Res. 58, 175-180.

Mariniva, P., Banskalieva, V., Alexandrov, S., Tzvetkova, V. \& Stanchev, H., 2001. Carcass composition and meat quality of kids fed sunflower oil supplemented diet. Small Rumin. Res. 42, 219-227.

Mountain meat goats. http://www.mountainmeatgoats.com/

Mourad, M., Gbanamou, G. \& Blade, I.B., 2001. Carcass characteristics of West African dwarf goats under extensive system. Small Rumin. Res. 42, 83-86.

Mtenga, L.A. \& Kitaly, A.J., 1990. Growth performance and carcass characteristics of Tanzanian goats fed Chloris gayana hay with different levels of protein supplement. Small Rumin. Res. 3, 1-8.

Mustapha, M. \& Kamal, H., 1982. A study of goat production under two systems of management. In: Animal Production and Health in the Tropics. Proc. First Asian-Australasian Animal Science Congress held in Serdang from the $2^{\text {nd }}$ to $5^{\text {th }}$ September 1980. pp. 329-332.

Okello, K.L., Ebong, C. \& Opuda-Asibo, J., 1994. Effect of feed supplements on weight gain and characteristics of intact male Mubende goats fed elephant grass (P. purpureum) ad libitum in Uganda. In: Proc $3{ }^{\text {rd }}$ Biennial Conference of the African Small Ruminant Research Network, Uganda.

Owen, J.E., Norman, G.A., Philbrooks, C.A. \& Jones, N.S.D., 1978. Studies on the meat production characterstics of Botswana goats and sheep. Part III: Carcass tissue composition and distribution. Meat Sci. 2, 59-74.

Payne, W.J.A. \& Wilson, R.T., 1999. An Introduction to Animal Husbandry in the Tropics, $5^{\text {th }}$ ed., Blackwell Science Ltd, London, U.K. pp. 815.

Perkin Elmer, 1982. Analytical Methods for Atomic Absorption Spectrophotometer. Perkin Elmer Corporation. Norwalk, Connecticut, USA. No. 0303-0152.

Ponnampalam, E.N., Hosking, B.J. \& Egan, A.R., 2003. Rate of carcass components gain, carcass characteristics and muscle longissimus tenderness in lambs fed dietary protein sources with a low quality roughage diet. Meat Sci. 63, 143-149.

Rao, V.K., Anjaneyulu, A.S.R. \& Lakshmanan, V., 1985. Carcass characteristics of market slaughter goats. Indian Vet. Med. J. 9, 53-55.

Reddy, T.J. \& Raghavan, G.V., 1988. Feedlot performance of stall-fed Telangana local goats on different diets. Indian J. Anim. Nutr. 5, 337-340.

Saikia, G., Baruah, K.K., Buragohain, S.C., Saikia, B.N. \& Brahma, M.L., 1996. Effect of various energy levels on carcass characteristics and body composition of male cross-bred kids. Indian Vet. J. 73, 31-34.

Samuels, M.L., 1989. Statistics for the Life Sciences. Collier MacMillan Publishers, London.

SAS, 2001. Statistical Analysis Systems User’s Guide. Statistics Version 8, SAS Institute Inc. Cary N.C., USA.

Sen, A.R., Santra, A. \& Karim S.A., 2004. Carcass yield, composition and meat quality attributes of sheep and goat under semiarid conditions. Meat Sci. 66, 757-763.

Seyoum Bediye \& Zinash Sileshi, 1989. The composition of Ethiopian feedstuffs. IAR Research Report No.6. IAR, Addis Ababa, Ethiopia.

Sheridan, R., Ferreira, A.V. \& Hoffman L.C., 2003. Production efficiency of South African Mutton Merino lambs and Boer goat kids receiving either a low or a high-energy feedlot diet. Small Rumin. Res. 50, 75-82.

Singh, D.K., Mishra, H.R., Singh, C.S.P. \& Singh, L.B., 1991. Factors affecting non-edible offals in the carcass of Black Bengal and its half breds with Jamunapari and Beetal kids. Indian J. Anim. Sci. 61, 1141-1143.

Snowder, G.D., Glimp, H.A. \& Field, R.A., 1994. Carcass characteristics and optimal slaughter weights in four breeds of sheep. J. Anim. Sci. 72, 932-937.

Tesfaye Alemu, T., Fidalis, M.N., Hoeven, E., Yadav, B.R., Hanotte, O. \& Hanlin, H., 2004. Genetic characterization of indigenous goat populations of Ethiopia using microsatellite DNA markers. In: Proc. $29^{\text {th }}$ Int. Conf. Animal Genetics, ISAG September 11-16, 2004, Tokyo, Japan.

Tesfaye Wolde Micheal, Osuji, P.O., Asfaw Yimegnuhal \& Alemu Yami, 2001. Effect of wheat bran supplementation on feed intake, body weight change and retained energy in the carcass of Ethiopian 
highland Zebu (Bos indicus) oxen fed teff straw (Eragrostis tef) as basal diet. Proc. $9^{\text {th }}$ Ethiopian Society of Animal Production, Ethiopia, Addis Abeba.

Tshabalala, P.A., Strydom, P.E., Webb, E.C. \& de Kock, H.L., 2003. Meat quality of designated South African indigenous goat and sheep breeds. Meat Sci. 65, 563-570.

Van Soest, P.J. \& Robertson, J.B., 1985. Analysis of forages and fibrous foods. A laboratory manual for animal science. Cornell University, Ithaca, New York, USA.

Van Soest, P.J., Robertson, J.B. \& Lewis, B.A., 1991. Methods for dietary, neutral detergent fiber, and non starch polysaccharides in relation to animal nutrition. Symposium: Carbohydrate methodology, metabolism, and nutritional implications in dairy cattle. J. Dairy Sci. 74, 3583-3597.

Webb, E.C., 1992. The influence of dietary energy levels on subcutaneous fatty acid profiles and meat quality in sheep. M.Sc thesis, University of Pretoria.

Webb, E.C., Casey, N.H. \& Simela, L., 2005. Goat meat quality. Small Rumin. Res. 60, 153-166.

Zinash Sileshi \& Seyoum Bediye, 1991. Utilization of feed resources and feeding systems in the central zone of Ethiopia. Proc. $3^{\text {rd }}$ National Livestock Improvement Conference. IAR, Addis Ababa, Ethiopia. pp. 129-132. 